\title{
KONTRIBUSI DIKLAT ONLINE TERHADAP CALON PEJABAT \\ FUNGSIONAL PENGEMBANG TEKNOLOGI PEMBELAJARAN
}

\section{ONLINE TRAINING CONTRIBUTION TO THE FUNCTIONAL OFFICIAL CANDIDATES OF INSTRUCTIONAL DESIGNERS}

\author{
Arie Kurniawan \\ Balai Pengembangan Media Radio Pendidikan dan Kebudayaan (BPMRPK-Kemendikbud), \\ Jl. Sorowajan Baru 367, Banguntapan, Yogyakarta, Indonesia \\ E-mail: arie.kurniawan@kemdikbud.go.id \\ Sudirman Siahaan \\ Pusat Kurikulum dan Perbukuan (Puskurbuk-Balitbang, Kemendikbud), \\ JI. Gunung Sahari Raya Nomor 4 Pasar Senen, Jakarta Pusat, DKI Jakarta, Indonesia \\ E-mail:pakdirman@yahoo.com
}

Diterima tanggal: 16 Agustus 2016, dikembalikan untuk direvisi tanggal: 29 Agustus 2016, disetujui tanggal: 10 September 2016

\begin{abstract}
ABSTRAK: Masalah yang menjadi fokus di dalam penelitian ini adalah mengenai kontribusi diklat online bagi calon pejabat fungsional Pengembang Teknologi Pembelajaran (JF-PTP) melalui fasilitas portal Rumah Belajar (Portal Rumbel). Tujuan penelitian adalah untuk untuk mengkaji sejauh mana kontribusi diklat online terhadap calon pejabat fungsional PTP, ditinjau dari aspek: (1) jumlah peserta; (2) persentase kelulusan; dan (3) kesulitan-kesulitan yang dihadapi dalam penyelenggaraan diklat online itu sendiri. Metode penelitian yang digunakan adalah analisis deskriptif yaitu mengolah dan menganalisis data dan informasi yang diperoleh dari responden dan dokumen serta menyajikannya secara deskriptif. Hasil penelitian menunjukkan bahwa diklat online mempunyai kontribusi yang cukup besar bagi calon pejabat fungsional PTP karena: (1) mampu meningkatkan jumlah peserta diklat bagi calon pejabat fungsional PTP; (2) mampu menghemat biaya pelaksanaan dan transportasi peserta; (3) mampu meningkatkan persentase kelulusan pada tahun pertama; dan (4) diperlukan kerjasama antara Pustekkom-Kemendikbud selaku penyelenggara diklat online dengan instansi asal peserta mengenai pemberian tugas tambahan selama mengikuti diklat online.
\end{abstract}

Kata Kunci: Diklat Online, Jabatan Fungsional Pengembang Teknologi Pembelajaran.

ABSTRACT: The problem focused in this study is about online training contribution for functional official candidates of instructional designers through the government-managed learning portal called Rumah Belajar. The aim of this study is to review online training contribution for official candidates of instructional designers from the aspects of: (1) the number of participants; (2) graduation percentage; and (3) problems encountered in the online training implementation. The method used is a descriptive analysis by processing and analyzing the data and information obtained from the respondents and available documents, and then presenting it descriptively. The result shows that online training has great a contribution for functional official candidates of instructional designers because: (1) it increases the number of online training participants for functional official candidates; (2) it saves some training cost; (3) it increases the graduation percentage at the first year; and (4) it needs some collaboration between ICT Centre for Education and Culture (Ministry of Education and Culture) and the institutions of the participants on the job awarding during the training.

Key Words: Online Training, Functional Office of Instructional Designers. 


\section{PENDAHULUAN}

Di dalam lingkungan Pegawai Negeri Sipil (PNS), dikenal dua jalur pengembangan karier, yaitu melalui jabatan struktural dan jabatan fungsional. Jabatan fungsional terdiri dari dua jenis, yaitu: jabatan fungsional umum dan jabatan fungsional tertentu. Jabatan fungsional tertentu ini dikelompokkan ke dalam 2 kategori, yaitu keterampilan dan keahlian. Dengan diberlakukannya Undang-Undang Nomor 5 Tahun 2014 tentang Aparatur Sipil Negara, PNS mempunyai kesempatan untuk memilih jalur pengembangan kariernya. Pengembangan karier PNS melalui jabatan fungsional tertentu yang bersifat keahlian harus memenuhi serangkaian persyaratan. Salah satu di antara persyaratannya adalah mengikuti pendidikan dan pelatihan (Diklat) dan dinyatakan lulus.

Pada umumnya, Diklat calon pejabat fungsional tertentu (di bidang apapun) dilaksanakan secara konvensional atau tatap muka dengan mengumpulkan peserta di tempat tertentu selama kurun waktu tertentu. Seiring dengan kemajuan Teknologi Informasi dan Komunikasi (TIK), Kementerian Pendidikan dan Kebudayaan (Kemendikbud) sebagai instansi pembina Jabatan Fungsional Pengembang Teknologi Pembelajaran (JF-PTP) merintis model Diklat Online bagi Calon Pejabat Fungsional PTP (Pustekkom, 2013). Tanggung jawab pelaksanaan Diklat ini dipercayakan pada Pusat Teknologi Informasi dan Komunikasi Pendidikan (Pustekkom).

Melalui berbagai pengalaman mengembangkan model/sistem pembelajaran yang inovatif yang memanfaatkan kemajuan TIK (adanya intervensi TIK) yang dapat meningkatkan efektivitas dan efisiensi kegiatan pembelajaran (Sadiman, 2008) dan beberapa pertimbangan lainnya selama melaksanakan Diklat secara konvensional, Pustekkom merancang dan mengembangkan model Diklat Online bagi calon pejabat fungsional PTP. Setelah selesai melaksanakan berbagai kegiatan persiapan, Pustekkom melakukan langkah lanjutan yaitu memulai perintisan penyelenggaraan Diklat Online-nya pada tahun 2013.
Apabila kita melakukan telaah terhadap Diklat konvensional, beberapa kendalanya adalah: (1) pesertanya harus meninggalkan tempat pekerjaan dan keluarga; dan (2) dibutuhkan biaya yang relatif tidak sedikit untuk: (a) perjalanan peserta dari berbagai tempat asal ke tempat penyelenggaraan Diklat, dan (b) tempat akomodasi serta konsumsi selama penyelenggaraan Diklat. Memperhatikan kendala-kendala dalam penyelenggaraan Diklat konvensional sebagaimana yang telah dikemukakan, berbagai lembaga pendidikan dan/atau pelatihan berinisiatif untuk mengembangkan upaya-upaya inovatif dalam penyelenggaraan Diklat dengan memanfaatkan kemajuan TIK. Salah satu upaya inovatif yang dimaksudkan dan yang akan dibahas di dalam tulisan ini adalah Diklat Calon Pejabat Fungsional PTP secara Online.

Pemikiran untuk penyelenggaraan Diklat Online didasarkan pada perkembangan TIK yang sangat pesat dari waktu ke waktu dan yang telah memengaruhi berbagai bidang kehidupan sehari-hari termasuk bidang pendidikan (Chaeruman, 2008; Warsita, 2011). Ketergantungan orang terhadap perangkat TIK semakin hari semakin tinggi, bahkan ada sebagian orang yang tidak dapat atau sulit melepaskan dirinya dari perangkat TIK di dalam kehidupan kesehariannya.

Pengaruh TIK terhadap kehidupan sehari-hari tidak hanya terjadi di kalangan masyarakat perkotaan saja tetapi sudah menjangkau masyarakat perdesaan yang jauh dari perkotaan. Beberapa di antara faktor penyebabnya adalah: (1) biaya pengadaan fasilitas/ perangkat TIK yang semakin hari semakin lebih terjangkau; (2) ketersediaan fasilitas/perangkat TIK dalam kehidupan sehari-hari yang memudahkan masyarakat untuk membelinya; dan (3) kualitas infrastruktur yang semakin membaik membuat masyarakat semakin dimudahkan melaksanakan berbagai ragam kegiatan kehidupan kesehariannya dengan dukungan TIK.

Dewasa ini, manakala kita mengunjungi berbagai lembaga pemerintah, termasuk lembaga-lembaga yang mempunyai tugas dan fungsi di bidang pendidikan dan/atau pelatihan, dapatlah dipastikan bahwa di lembaga tersebut tersedia perangkat TIK 
seperti komputer, LCD proyektor, layar, dan koneksi internet. Lembaga atau kantor pendidikan, baik yang ada di pusat (di lingkungan Kemendikbud) maupun yang ada di daerah telah terkoneksi dengan Jejaring Pendidikan Nasional (Jardiknas) yang memungkinkan terjadinya koneksi internet.

Memperhatikan berbagai keadaan tersebut di atas, kemajuan TIK yang sedemikian pesat perlu dimanfaatkan secara tepat di dalam penyelenggaraan Diklat (terencana dan terpadu) yang tentunya akan dapat memberikan nilai tambah yang signifikan dan meningkatkan efisiensi. Dalam kaitan ini, Pustekkom telah merancang dan mengembangkan sebuah fasilitas pembelajaran berupa portal yang diberi nama Portal Rumah Belajar (Portal Rumbel) pada tahun 2011 (Kompas, 2011).

Salah satu fitur yang disediakan di dalam Portal Rumbel adalah Pengembangan Keprofesian Berkelanjutan (PKB). Fitur inilah yang dimanfaatkan sebagai wahana untuk pelaksanaan Diklat Online bagi calon pejabat fungsional PTP. Sekalipun masih ada beberapa kekurangan pada fitur PKB ini, Pustekkom berketetapan untuk memanfaatkannya seraya melakukan penyempurnaan dalam proses penyelenggaraannya. Pelaksanaan Diklat Online calon pejabat fungsional PTP ini dimulai pada tahun 2013.

Diklat calon pejabat fungsional PTP secara konvensional atau yang sepenuhnya secara tatap muka diselenggarakan pertama kali pada tahun 2012 dan hanya diikuti oleh 17 orang PNS. Kemudian, pada tahun 2013, untuk yang pertama kali Diklat diselenggarakan secara online dan diikuti oleh 32 orang PNS calon pejabat fungsional PTP. Selanjutnya pada tahun 2014, jumlah peserta Diklat Online calon pejabat fungsional PTP mengalami peningkatan yang sangat signifikan, yaitu menjadi 181 orang PNS yang berasal dari berbagai lembaga di pusat dan daerah. Berbagai masukan terhadap penyelenggaraan Diklat Online, baik yang disampaikan oleh peserta maupun oleh instruktur, diterima dan ditelaah serta digunakan oleh Pustekkom untuk menyempurnakan model/sistem Diklat Online-nya.

Artikel hasil penelitian ini bertujuan untuk mengkaji sejauh mana kontribusi Diklat Online terhadap calon pejabat fungsional PTP, ditinjau dari aspek: 1) jumlah peserta; 2) persentase kelulusan; dan 3) kesulitankesulitan yang dihadapi dalam penyelenggaraan Diklat Online itu sendiri.

\section{KAJIAN LITERATUR \\ Diklat Konvensional ke Diklat Online}

Secara umum, bentuk penyelenggaraan pendidikan atau pendidikan dan pelatihan (Diklat) dapat dibedakan menjadi: (1) secara konvensional atau tatap muka (face-to-face or conventional learning or training); (2) secara jarak jauh (open or distance learning or training); dan (3) gabungan antara tatap muka dengan jarak jauh (blended learning or training).

Ketiga bentuk Diklat tersebut di atas dapat memanfaatkan TIK di dalam kegiatan pembelajarannya. Sistem belajar jarak jauh dapat diselenggarakan dengan mengandalkan: (1) bahan belajar mandiri tercetak (modul) diikuti dengan seminimal mungkin atau tanpa kegiatan belajar tutorial tatap muka; (2) pemanfaatan TIK di dalam keseluruhan aktivitas belajar; dan (3) bahan belajar tercetak dan TIK, dan/atau tutorial tatap muka.

Diklat Online pada dasarnya merupakan suatu Diklat yang memanfaatkan internet dan berbasis web guna memfasilitasi pembelajaran dan proses membangun pengetahuan melalui interaksi yang bermakna (Dabbagh, 2005). Senada dengan pendapat Dabbagh ini, Jolliffe menyatakan bahwa Diklat Online menggunakan bantuan server web untuk menjembatani proses penyampaian materi pembelajaran (Jolliffe, 2001).

Pada awalnya, Diklat untuk calon pejabat fungsional PTP diselenggarakan sepenuhnya secara konvensional (tatap muka) dengan menggunakan bahan belajar mandiri tercetak (modul). Berdasarkan hasil kajian internal disimpulkan bahwa dengan Diklat konvensional, sangat terbatas jumlah PNS yang dapat dilayani. Selain itu, peserta juga harus meninggalkan tempat tugas dan keluarganya dalam kurun waktu yang relatif lama serta biaya yang dibutuhkan juga relatif besar (perjalanan, akomodasi, dan konsumsi).

Memperhatikan adanya keterbatasan Diklat konvensional di satu sisi, perkembangan TIK yang sangat pesat dan berkembangnya kebutuhan staf di 
berbagai lembaga terhadap jabatan fungsional PTP di sisi yang lain, Pustekkom memutuskan untuk meninggalkan model Diklat konvensional dan sekaligus merintis penyelenggaraan model Diklat secara online untuk PNS yang berminat menjadi calon pejabat fungsional PTP.

Sebelum memulai upaya perintisan penyelenggaraan Diklat Online Calon Pejabat Fungsional PTP, Pustekkom melalui Kemendikbud telah mencanangkan "Program Layanan Teknologi Informasi dan Komunikasi Pembelajaran" pada tanggal 15 Juli 2011 (http://edukasi.kompas.com/ read/2011/07/15/18332747/Belajar. Tanpa.Batas. di.Rumah.Belajar).

Salah satu program dari layanan TIK untuk pembelajaran yang dicanangkan oleh Menteri Pendidikan dan Kebudayaan adalah portal Rumah Belajar yang dapat diakses melalui http:// belajar.kemdikbud.go.id. Pada awalnya, portal Rumah Belajar ini menyediakan lima fitur, yaitu Wahana Jelajah Angkasa, Rancangan Pelaksanaan Pembelajaran (RPP), Katalog Media, Bahan Belajar Interaktif, dan Bank Soal.

Pada perkembangan berikutnya, Portal Rumah Belajar menyediakan 12 fitur, yaitu Kelas Maya, Sumber Belajar, Buku Kurikulum 2013, Wahana Jelajah Angkasa, Anugerah Kihajar, Kuliah Daring Indonesia Terbuka dan Terpadu (KDITT), Sekolah Menengah Terbuka, Klinik Konsultasi Pembelajaran, Pengembangan Profesi Berkelanjutan, Peta Budaya, Karya Komunitas, dan Klub Pompi (Kerjasama dengan Badan Pengawasan, Obat, dan Makanan) lihat Gambar 1.

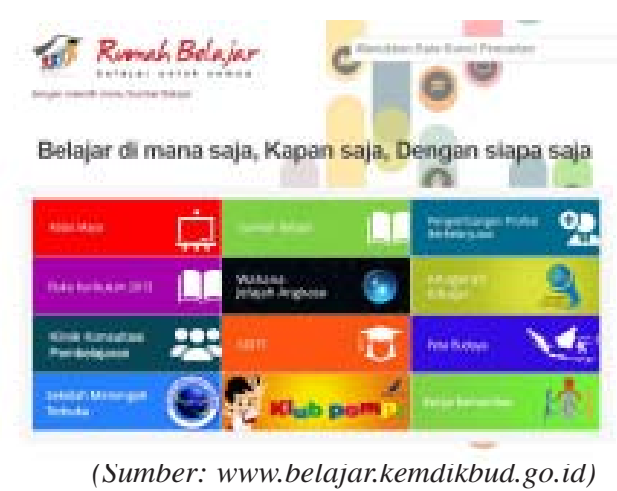

\section{Penelitian yang Relevan}

Bererapa kendala yang dihadapi oleh lembaga penyelenggara Diklat secara tatap muka adalah: (1) besarnya biaya yang dikeluarkan untuk biaya akomodasi dan transportasi peserta; (2) keharusan peserta meninggalkan keluarga; dan (3) lamanya waktu pelaksanaan Diklat yang menyebabkan terbengkalainya tugas rutin sehari-hari peserta. Diklat Online ini diharapkan mampu menyelesaikan permasalahan tersebut. Peserta yang mengikuti Diklat Online masih dimungkinkan untuk melaksanakan tugas sehari-harinya karena mereka tidak perlu meninggalkan tempat tugas. Selain itu, biaya transportasi juga tidak diperlukan karena peserta tidak perlu mendatangi lembaga penyelenggara Diklat.

Hasil kajian yang dilakukan oleh Epa Elfitriadi menunjukkan bahwa model blended learning sebagai penerapan e-learning di lingkungan Kementerian Agama ternyata dinilai kurang efisien dari aspek biaya dan jumlah jangkauan peserta. Model blended learning ini meliputi kegiatan tatap muka yang dilakukan minimal 3 kali berupa tutorial berbasis masalah pembelajaran. Ironisnya, proses tatap muka yang mengumpulkan peserta dalam satu tempat tersebut justru menjadi penyebab tingginya alokasi anggaran Diklat Jarak Jauh (DJJ) yang dilakukan.

Kekurangan lain dari model blended learning ini adalah kuota peserta DJJ yang berkisar antara 2030 orang per kelas sehingga menjadikan daya serap jumlah peserta DJJ tidak berbeda secara signifikan dibandingkan dengan Diklat reguler. Berdasarkan hasil evaluasi tersebut, PusDiklat Teknis Kementerian Agama kemudian mengembangkan sistem DJJ dari blended learning menjadi DJJ full online karena dinilai lebih banyak keuntungannya (http://www.pusDiklat teknis.kemenag.go.id/index.php/berita-ilmiah/artikel/ 125-menuju-Diklat-jarak-jauh-fully-online).

\section{METODE PENELITIAN}

Metode penelitian yang digunakan dalam penelitian tentang kontribusi Diklat Online terhadap calon pejabat fungsional pengembang teknologi pembelajaran ini adalah metode deskriptif. Metode deskriptif merupakan metode yang digunakan untuk 
mencari unsur-unsur, ciri-ciri, dan sifat-sifat dari suatu fenomena. Metode ini dimulai dengan mengumpulkan data, menganalisis data, dan kemudian menginterpretasikannya. Pada pelaksanaannya, metode deskriptif dilakukan melalui: teknik survei, studi kasus, studi komparatif, studi tentang waktu dan gerak, analisis tingkah laku dan analisis dokumenter (Suryana, 2010). Data yang digunakan dalam penelitian ini adalah data peserta Diklat Calon Pejabat Fungsional PTP, baik secara konvensional maupun secara online selama tahun 2012 sampai dengan 2014 yang diperoleh dari Pustekkom Kemendikbud.

Subyek yang diteliti dalam penelitian ini adalah seluruh peserta Diklat calon pejabat fungsional PTP, baik yang mengikuti Diklat secara konvensional maupun yang mengikuti Diklat secara online dari mulai tahun 2012 sampai dengan tahun 2014. Teknik analisis data yang digunakan dalam penelitian ini adalah teknik analisis deskriptif, yang artinya mendeskripsikan serta memaknai data peserta Diklat calon pejabat fungsional PTP mulai tahun 2012 sampai dengan tahun 2014.

\section{HASIL DAN PEMBAHASAN}

Pada Tabel 1 berikut ini disajikan data tentang jumlah peserta Diklat calon pejabat fungsional PTP dan lulusannya, baik yang mengikuti Diklat secara konvensional pada tahun 2012 maupun secara online pada tahun 2013 dan 2014.

Tabel-1: Jumlah Peserta Diklat JF-PTP dan Lulusan

\begin{tabular}{cccc}
\hline & \multicolumn{3}{c}{ Tahun } \\
\cline { 2 - 4 } Kategori & 2012 & 2013 & 2014 \\
\hline $\begin{array}{c}\text { Peserta dari } \\
\text { Pustekkom }\end{array}$ & 13 & 0 & 7 \\
\hline $\begin{array}{c}\text { Peserta dari } \\
\text { Luar Pustekkom }\end{array}$ & 4 & 32 & 174 \\
\hline $\begin{array}{c}\text { Total peserta dan } \\
\text { prosentase pe- } \\
\text { ningkatannya (\%) }\end{array}$ & 17 & $32(88,23)$ & $181(565,62)$ \\
\hline $\begin{array}{c}\text { Lulusan dan } \\
\text { prosentase (\%) }\end{array}$ & $12(70,59)$ & $23(71,87)$ & $101(55,80)$ \\
\hline
\end{tabular}

Sumber: Pustekkom 2014c

\section{Jumlah Peserta}

Diklat Online merupakan model Diklat yang memanfaatkan kemajuan TIK dalam keseluruhan kegiatannya sehingga memungkinkan peserta mengikuti kegiatan Diklat dari tempatnya masingmasing tanpa harus meninggalkan tugas sehari-hari dan keluarganya. Oleh karena itu, setiap peserta harus memiliki pengetahuan dan keterampilan di bidang komputer dan internet.

Sebagaimana yang telah diuraikan pada bagian pendahuluan, ketetapan Pustekkom untuk merintis penyelenggaraan Diklat Online bagi calon pejabat fungsional PTP didasarkan pada beberapa pertimbangan, yaitu antara lain bahwa melalui Diklat Online: (1) peserta masih tetap dapat melaksanakan tugas sehari-harinya dan juga tidak perlu meninggalkan keluarganya; (2) biaya penyelenggaraan Diklat Online relatif kecil sehingga dapat menghemat biaya perjalanan, akomodasi dan konsumsi; (3) kemajuan TIK memungkinkan peserta memanfaatkannya untuk mengikuti keseluruhan kegiatan Diklat Online; dan (4) adanya dukungan fasilitas/perangkat TIK yang dibutuhkan untuk mengikuti kegiatan Diklat Online.

Diklat secara online ini diterapkan juga oleh beberapa lembaga selain Pustekkom Kemendikbud karena dirasa banyak manfaatnya. Manfaat yang dimaksud antara lain mampu meningkatkan jumlah peserta dibandingkan jika Diklat dilaksanakan secara konvensional. Beberapa lembaga yang dimaksud antara lain: (1) Pusat Pengembangan dan Pemberdayaan Pendidik dan Tenaga Kependidikan Ilmu Pengetahuan Alam (P4TK IPA) Bandung yang mulai menyelenggarakan Diklat Online pada tahun 2012 dengan peserta guru IPA; (2) Pusat Pengembangan dan Pemberdayaan Pendidik dan Tenaga Kependidikan Bidang Taman Kanak-Kanak dan Pendidikan Luar Biasa (P4TK TK dan PLB) Bandung yang telah menyelenggarakan Diklat Online atau e-training sejak tahun 2003. (http://etraining.tkplb.org/mod/page/ view.php?id =436); (3) Pusat Pengembangan dan Pemberdayaan Pendidik dan Tenaga Kependidikan Bidang Otomotif dan Elektronika (P4TK BOE) Malang yang mulai menyelenggarakan pelatihan guru secara online pada tahun 2014; serta (4) Balai Diklat 
Kementerian Agama di Semarang. Balai Diklat ini merupakan bagian dari Pusdiklat Tenaga Teknis Pendidikan dan Keagamaan Badan Litbang dan Diklat Kementerian Agama. Balai Diklat ini pernah menyelenggarakan Diklat secara online untuk 4 angkatan pada rentang waktu tahun 2010-2012. (http://djj.pusDiklatteknis. kemenag.go.id/).

Sebagai syarat untuk dapat mengikuti kegiatan Diklat Online Calon Pejabat Fungsional PTP, seorang PNS harus memenuhi serangkaian persyaratan, yaitu: (1) minimal berada pada pangkat Penata Muda dengan golongan ruang III/a; (2) berlatar belakang pendidikan Strata-1 (S-1)/Diploma-4 dengan disiplin ilmu pendidikan, ilmu komunikasi, dan ilmu komputer dengan berbagai derivasinya (Kementerian Pendidikan dan Kebudayaan, 2014); (3) berkiprah/ bekerja di lembaga pendidikan dan/atau pelatihan atau lembaga yang tugas dan fungsinya mengenai pengembangan atau penerapan TIK; (4) mengajukan surat permohonan yang menyatakan minatnya untuk menjadi tenaga fungsional PTP; dan (5) surat permohonan yang disetujui oleh pimpinan satuan kerja.

Sampai dengan tahun 2014, Pustekkom telah menyelenggarakan Diklat bagi calon pejabat fungsional PTP sebanyak tiga kali berturut-turut, satu kali secara konvensional (tahun 2012) dan dua kali secara online (tahun 2013 dan 2014). Setiap periode pelaksanaan Diklat calon pejabat fungsional PTP, jumlah peserta mengalami peningkatan. Satu hal yang menarik untuk dicermati dari Tabel-1 di atas adalah peningkatan jumlah peserta Diklat secara online pada tahun 2014 yang cukup signifikan yaitu dari 32 orang peserta pada tahun 2013 meningkat menjadi 181 orang peserta pada tahun berikutnya.

Setelah Diklat calon pejabat fungsional PTP dilaksanakan secara online, jumlah peserta dari luar Pustekkom tampak melonjak tinggi. Peserta dari Pustekkom sendiri yang berminat menjadi tenaga fungsional PTP telah memanfaatkan fasilitas inpassing. Peningkatan jumlah peserta yang cukup signifikan ini disinyalir terjadi karena Pustekkom sebagai instansi penyelenggara terus melakukan sosialisasi mengenai Diklat Online bagi calon pejabat fungsional PTP ini secara berkelanjutan ke berbagai lembaga. Hal tersebut bak gayung bersambut dengan tingginya minat PNS untuk menjadi pejabat fungsional PTP.

Diklat Online calon pejabat fungsional PTP ini menawarkan beberapa keuntungan dibandingkan Diklat secara konvensional. Keuntungan yang dirasakan oleh peserta ini menyebabkan adanya peningkatan jumlah peserta Diklat pada gelombang berikutnya. Diklat yang dilaksanakan secara online memungkinkan PNS tetap dapat mengerjakan tugas rutinnya selama mengikuti Diklat karena tidak perlu mendatangi lembaga penyelenggara Diklat (dalam hal ini adalah Pustekkom-Kemendikbud).

Perkembangan yang terjadi sejauh ini adalah bahwa masih sangat sedikit jumlah PNS di luar lingkungan Kemendikbud yang telah mengikuti Diklat calon pejabat fungsional PTP (masih terbatas di lingkungan Dinas Pendidikan Provinsi). Oleh karena itu, sosialisasi Diklat Online calon pejabat fungsional PTP ini perlu terus-menerus ditingkatkan, tidak hanya di lingkungan Kemendikbud tetapi juga di berbagai lembaga di luar Kemendikbud.

\section{Persentase Kelulusan}

Hal lain yang juga menarik untuk mendapat perhatian adalah menurunnya tingkat kelulusan peserta Diklat pada tahun ketiga (dari 71,87\% menjadi $55,80 \%$ ). Pertanyaannya adalah faktor-faktor apa yang menjadi penyebabnya. Proses pembelajaran pada Diklat Online calon pejabat fungsional PTP ini menggunakan model pembelajaran terbuka jarak jauh secara online/daring (dalam jaringan) dengan komposisi pembelajarannya $80 \%$ belajar mandiri, dan $20 \%$ bimbingan tutorial secara online/daring. Belajar mandiri tidak harus belajar sendiri, tetapi dimungkinkan juga untuk belajar di dalam kelompok kecil, yang tidak harus tergantung pada bantuan orang lain (instruktur, teman sesama peserta didik maupun orang lain (Haryono, 2001).

Salah satu ciri khas Diklat Online adalah adanya perbedaan ruang dan waktu antara pengajar dengan peserta, sehingga diperlukan bahan belajar yang dirancang secara khusus sehingga mampu mengatasi permasalahan tersebut. Bahan belajar tersebut disusun sedemikian rupa sehingga memungkinkan peserta untuk mempelajarinya tanpa bantuan dari orang lain. Semua informasi yang 
diperlukan untuk mencapai tujuan pembelajaran telah tersedia di bahan belajar tersebut sehingga peserta didik tidak perlu mencari informasi di tempat lain (Lasmono, 2011).

Bahan belajar yang dirancang secara khusus merupakan salah satu komponen dari pembelajaran jarak jauh/Diklat Online. Syarat yang harus dipenuhi oleh bahan belajar Diklat Online ini adalah: (1) rumusan tujuan belajar yang jelas; (2) dikembangkan setahap demi setahap, dikemas mengikuti alur desain pesan, seperti keseimbangan pesan verbal dan visual; (3) bahan belajar merupakan sistem pembelajaran yang lengkap, terdiri dari rumusan tujuan belajar, materi belajar, contoh/bukan contoh, evaluasi penguasaan materi, petunjuk belajar dan rujukan bacaan; (4) bahan belajar dapat disampaikan melalui berbagai media meliputi media cetak, atau komputerisasi, atau program audio/video; (5) bahan belajar bisa dikirim dengan menggunakan jasa pos, atau menggunakan teknologi canggih dengan internet dan email, atau dengan cara lain yang dianggap mudah dan terjangkau oleh peserta didik; dan (6) penyampaian bahan belajar dapat disertai dengan program tutorial yang diselenggarakan berdasarkan jadwal dan lokasi tertentu atau sesuai dengan kesepakatan bersama (Lasmono, 2011).

Bahan belajar pada Diklat Online harus mampu mewakili kehadiran pengajar serta mampu membelajarkan peserta Diklat. Oleh sebab itu, bahan belajar yang digunakan dalam Diklat Online dikemas sedemikian rupa, yaitu kombinasi antara media cetak, audio, video, komputer, serta media presentasi. Bahan belajar yang berkualitas baik akan mampu mendukung proses pembelajaran peserta Diklat, yang pada akhirnya akan memudahkan peserta Diklat mencapai tujuan pembelajaran. Tidak berlebihan jika dikatakan bahwa mutu bahan belajar Diklat Online menentukan tingkat kelulusan peserta Diklat.

Berdasarkan hasil penelitian, bahan belajar yang digunakan dalam program Diklat Online Calon Pejabat Fungsional PTP ini memiliki kualitas yang baik untuk bahan belajar modul dan media presentasi. Sebanyak 91,85\% responden menyatakan bahwa bahan belajar modul mampu membantu peserta untuk mencapai kompetensi, dan $87,31 \%$ responden berpendapat bahwa media presentasinya mudah untuk dimengerti serta memiliki materi yang aktual (Warsita, 2016).

Pembelajaran jarak jauh, dalam hal ini Diklat Online calon pejabat fungsional PTP, menuntut pembelajar untuk berperan sebagai subyek utama. Dia memegang kendali penuh atas dirinya, mengambil keputusan dan mengambil inisiatif atas belajarnya sendiri. Banyak peserta Diklat Online yang gagal mencapai kompetensi yang diharapkan karena tidak mampu mengelola proses pembelajarannya.

Berdasarkan hasil evaluasi yang sudah dilakukan, mayoritas peserta Diklat Online Calon Pejabat Fungsional PTP menghadapi kendala berupa: (1) kesibukan atau tuntutan pelaksanaan tugas sehariharinya di instansi tempat bekerja; (2) tuntutan untuk melaksanakan tugas dinas keluar kota sehingga aktivitas belajarnya menjadi terganggu; (3) kondisi infrastruktur yang kurang mendukung; dan (4) pemahaman dalam mempelajari materi Diklat (Pustekkom, 2014a).

Berbagai upaya untuk menunjang pelaksanaan Diklat Online dilihat dari segi peserta diantaranya adalah: (1) perlu disusun materi pembelajaran yang lebih menarik dan mudah dipahami sehingga mampu meningkatkan motivasi belajar peserta; (2) perlu ada kerjasama antara instansi asal peserta dengan Pustekkom sebagai lembaga penyelenggara Diklat Online calon pejabat fungsional PTP sehingga pemberian tugas tambahan ataupun tugas keluar kota dapat dipertimbangkan; dan (3) perlu diupayakan juga agar pemberian tugas keluar kota (kalau memang harus dilakukan) dapat disesuaikan dengan jadwal tutorial yang sudah ditetapkan sehingga tidak bentrok dan merugikan peserta. Dengan demikian, diharapkan peserta Diklat dapat mengikuti seluruh rangkaian aktivitas Diklat Online tanpa terganggu ataupun mengganggu tugas rutinnya.

\section{Faktor-faktor Penunjang dan Penghambat Pelaksanaan Diklat Online Faktor Penunjang}

Beberapa faktor penunjang pelaksanaan Diklat Online ini adalah: (1) peserta Diklat dapat mengatur waktu dan kegiatannya sehingga dapat mengikuti 
Diklat secara optimal; (2) peserta dapat mengakses dan mengunduh materi Diklat sambil beraktivitas, dan kemudian mempelajarinya kapan saja dan di mana saja, tanpa perlu meninggalkan tugas utamanya; (3) dapat berinteraksi dengan peserta Diklat dari daerah lain; (4) dapat menjangkau peserta Diklat secara luas dan massive; (5) memberi peluang kepada peserta Diklat untuk berkolaborasi dengan sesamanya yang tersebar di berbagai daerah/lokasi dengan latar belakang yang beragam; dan (6) biaya penyelenggaraan Diklat Online dinilai relatif lebih murah dibandingkan dengan Diklat secara konvensional.

\section{Faktor Penghambat}

Beberapa faktor yang menghambat pelaksanaan Diklat Online calon pejabat fungsional PTP, antara lain adalah: (1) beberapa tempat mempunyai koneksi internet yang relatif lambat; (2) kesibukan peserta Diklat Online di instansi tempat tugasnya yang cukup menyita waktu sehingga mengurangi porsi waktu untuk kepentingan kegiatan belajar mandirinya; dan (3) ketersediaan sumber tenaga listrik di beberapa daerah yang kurang stabil.

\section{SIMPULAN DAN SARAN Simpulan}

Diklat Online memiliki kontribusi yang besar bagi peningkatan jumlah calon pejabat fungsional PTP karena mampu: (1) melayani peserta Diklat dalam jumlah yang besar tanpa harus meninggalkan rutinitas sehari-hari di tempat kerja mereka; (2) menghemat biaya terutama biaya akomodasi dan transportasi peserta Diklat, karena mereka tidak perlu mendatangi tempat pelaksanaan Diklat; dan (3) meningkatkan persentase kelulusan peserta Diklat Online pada tahun pertama sekalipun pada tahun kedua terdapat penurunan yang kemungkinan disebabkan oleh kesibukan peserta sehingga mereka tidak bisa aktif mengikuti proses pembelajaran. Selain berkontribusi, Diklat Online juga mempunyai beberapa hambatan dalam penerapannya, yaitu antara lain: beberapa tempat memiliki koneksi internet yang kurang bagus (lambat/lemah) sehingga sangat mengganggu proses pembelajaran peserta Diklat terutama ketika mereka mengikuti ujian akhir, dan beberapa peserta Diklat memiliki keterbatasan waktu belajar dikarenakan melaksanakan tugas kedinasan keluar kota.

\section{Saran}

Mengingat adanya peningkatan: (1) jumlah lembaga yang mengirimkan staf dan sekaligus juga (2) jumlah peserta yang mengikuti Diklat Online calon pejabat fungsional PTP, kegiatan sosialisasi jabatan fungsional PTP ke berbagai lembaga pendidikan dan Diklat, baik di dalam maupun di luar Kementerian Pendidikan dan Kebudayaan, perlu terus ditingkatkan melalui berbagai media.

Memperhatikan adanya penurunan tingkat atau persentase kelulusan peserta Diklat Online, perlu dilakukan evaluasi terhadap model/sistem Diklat Online beserta komponennya agar semakin baik dan menarik, sehingga mempermudah peserta dalam: (1) memahami materi Diklat Online, dan (2) mengikuti keseluruhan kegiatan Diklat Online.

Pustekkom-Kemendikbud sebagai instansi penyelenggara Diklat Online calon pejabat fungsional PTP perlu melakukan kerjasama dengan instansi asal peserta Diklat, sehingga selama mengikuti Diklat Online, peserta tidak diberikan tugas tambahan yang akan mengganggu proses belajarnya.

\section{PUSTAKA ACUAN}

Chaeruman, Uwes A. 2008. Mendorong Penerapan E-learning di Sekolah, artikel dalam Jurnal IImiah TEKNODIK Vol. XII No.

1, Ciputat-Tangerang Selatan: Pusat Teknologi Informasi dan Komunikasi Pendidikan-Kementerian Pendidikan Nasional. Dabbagh, Nada dan Bannan-Ritland, Brenda. 2005. Online Learning: Concepts, Strategies, and Application. New Jersey: Pearson Education, Inc.

Haryono, Anung. 2001. Belajar mandiri: konsep dan penerapannya dalam sistem pendidikan dan pelatihan terbuka/jarak jauh. Sumber: http://lppm.ut.ac.id/ptj// PTJJ\%20Vol\%202.2\%20september\%202001/22anung.htm (diakses tanggal 25 Februari 2015). 
Jolliffe, Alan \& Ritter, Jonathan \& Stevens, David. 2001. The Online Learning Handbook: Developing and Using Web-Based Learning. London: Kogan Page.

Kompas.com. 2011. "Belajar Tanpa Batas di Rumah Belajar". Sumber: Website: http:// edukasi.kompas.com/read/2011/07/ 15/18332747/Belajar.Tanpa.Batas.di.Rumah. Belajar (diakses tanggal 16 Februari 2015).

Lasmono, Suharto. 2011. Modul belajar mandiri pada pendidikan terbuka jarak jauh. Ciputat-Tangerang Selatan: PustekkomKemdiknas.

Pusat Pengembangan dan Pemberdayaan Pendidik dan Tenaga Kependidikan Matematika. Diklat Online Guru Matematika. Sumber: http://Diklatonline.p4tkmatematika.org/(diakses tanggal 18 Februari 2015).

Pusat Pengembangan dan Pemberdayaan Pendidik dan Tenaga Kependidikan Ilmu Pengetahuan Alam (P4TK IPA) Bandung. Diklat Online Guru IPA. Sumber: http://118.98.221.68/files/pedoman.pdf (diakses tanggal 18 Februari 2015).

Pusat Pengembangan dan Pemberdayaan Pendidik dan Tenaga Kependidikan Bidang Taman Kanak-Kanak dan Pendidikan Luar Biasa (P4TK TK dan PLB) Bandung. Penyusunan dan Penyelesaian KTI. Sumber: http:// etraining.tkplb.org/mod/ page/view.php? id=436 (diakses tanggal 18 Februari 2015).

Pustekkom-Kemdikbud, 2013. Panduan Orien-tasi Peserta Diklat Online Calon Pejabat Fungsional Pengembang Teknologi Pembelajaran. Ciputat-Tangerang Selatan: Pustekkom-Kemdikbud.

Pustekkom-Kemdikbud, 2014a. Laporan Evaluasi Program Pendidikan dan Pelatihan Calon Pejabat Fungsional Pengembang Teknologi Pembelajaran Secara Online/Daring. Ciputat-Tangerang Selatan: Pustekkom-Kemdikbud.

Pustekkom-Kemdikbud, 2014b. Petunjuk pelaksanaan pendidikan dan pelatihan Calon Pejabat fungsional pengembang teknologi pembelajaran secara online/daring. Ciputat-Tangerang Selatan: Pustekkom-Kemdikbud.

Pustekkom-Kemdikbud, 2014c. Data peserta Diklat calon pejabat fungsional PTP tahun 2012-2014. Ciputat-Tangerang Selatan: Pustekkom-Kemdikbud.

Sadiman, Arief S. 2008. Pemanfaatan ICT untuk Pendidikan Pencegahan HIVIAIDS di Daerah Perbatasan Greater Mekong Subregion, artikel dalam Jurnal IImiah TEKNODIK Vol. XII No. 1, Ciputat-Tangerang Selatan: Pusat Teknologi Informasi dan Komunikasi Pendidikan-Kementerian Pendidikan Nasional.

Suryana. 2010. Metodologi Penelitian: model praktis penelitian kuantitatif dan kualitatif, bahan ajar perkuliahan. Universitas Pendidikan Indonesia.

Undang-Undang Nomor 5 Tahun 2014 tanggal 15 Januari 2014 tentang Aparatur Sipil Negara. Jakarta: Kementerian Sekretariat Negara Republik Indonesia. Sumber Internet:http://kelembagaan.ristekdikti.go. id/wp-content/uploads/2016/ 08/UU5-2014_Aparatur_Sipil_Negara.pdf). (diakses tanggal 2 Maret 2015).

Warsita, Bambang. 2011. Landasan Teori dan Teknologi Informasi dalam Pengembangan Teknologi Pembelajaran, artikel dalam Jurnal IImiah TEKNODIK Vol. XV No. 1 (Terakreditasi LIPI), Ciputat-Tangerang Selatan: Pusat Teknologi Informasi dan Komunikasi Pendidikan-Kementerian Pendidikan Nasional.

Warsita, Bambang. 2016. Evaluasi bahan belajar Diklat online calon pejabat fungsional pengembang teknologi pembelajaran, artikel dalam Jurnal IImiah TEKNODIK Vol. 20 No. 1, Ciputat-Tangerang Selatan: Pusat Teknologi Informasi dan Komunikasi Pendidikan dan Kebudayaan-Kementerian Pendidikan dan Kebudayaan.

Website:http://edukasi.kompas.com/read/2011/07/15/18332747/Belajar.Tanpa.Batas.di.Rumah.Belajar (diakses tanggal 2 Maret 2015).

Website:http://djj.pusDiklatteknis.kemenag.go.id/ (diakses tanggal 18 Februari 2015).

Website:www.belajar.kemdikbud.go.id/ptp/ (diakses tanggal 17 Februari 2015).

Website: http://www.pusDiklatteknis.kemenag.go. id/index.php/berita-ilmiah/artikel/125-menuju-Diklat-jarak-jauh-fully-online (diakses tanggal 31 Oktober 2016).

\section{UCAPAN TERIMAKASIH}

Kami mengucapkan terima kasih kepada Dr. Oos M. Anwas yang telah memberikan masukan dan koreksinya, sehingga artikel ini dapat diterbitkan. 